Article

\title{
Hydrogen Production from Ethylene Glycol Aqueous Phase Reforming over Ni-Al Layered Hydrotalcite-Derived Catalysts
}

\author{
Jianguang Zhang ${ }^{1}$ and Ningge $\mathrm{Xu}{ }^{2, *}$ \\ 1 School of Petroleum Engineering, China University of Petroleum (East China), Qingdao 266580, China; \\ eduzjg@163.com or zhangjianguang@upc.edu.cn \\ 2 Equipment Engineering Teaching and Research Office, Army Logistics University of PLA, \\ Chongqing 400030, China \\ * Correspondence: xuningge12@163.com; Tel.: +86-182-0227-9563
}

Received: 12 November 2019; Accepted: 5 December 2019; Published: 1 January 2020

\begin{abstract}
By introducing $\mathrm{Mg}, \mathrm{Cu}, \mathrm{Zn}, \mathrm{Sn}$, and $\mathrm{Mn}$ into the synthesis processes of $\mathrm{Ni}$ and $\mathrm{Al}$ based hydrotalcite, $\mathrm{Ni}-\mathrm{Al}$ layered hydrotalcite-derived catalysts with different metal compositions were prepared. In this paper, the effect of metal composition on the structure of $\mathrm{Ni}-\mathrm{Al}$ layered hydrotalcite-derived catalysts is investigated, and then catalytic activities of prepared catalysts with different metal compositions on ethylene glycol aqueous-phase reforming are analyzed. The physicochemical properties of the $\mathrm{Ni}-\mathrm{Al}$ layered hydrotalcite-derived catalysts were characterized by X-ray diffraction (XRD), temperature-programmed reduction (TPR), and nitrogen adsorption-desorption technology. The obtained hydrotalcite-derived catalysts were applied to the process of ethylene glycol aqueous-phase reforming (APR). The XRD results confirmed that the precursors of hydrotalcite-derived catalysts with metal compositions of Ni/Mg/Al, Ni/Cu/Al, Ni/Zn/Al, and $\mathrm{Ni} / \mathrm{Sn} / \mathrm{Al}$ had hydrotalcite crystalloid morphology. During the process of ethylene glycol aqueous phase reforming, all the catalysts showed high conversion of ethylene glycol (>90\%), and the optimum hydrogen yield (73.5\%) was obtained when using the catalyst with metal composition of $\mathrm{Ni} / \mathrm{Mg} / \mathrm{Al}$ at $225^{\circ} \mathrm{C}$ under 2.6 MPa in nitrogen atmosphere for $2.5 \mathrm{~h}$.
\end{abstract}

Keywords: hydrogen; aqueous-phase reforming; ethylene glycol; hydrotalcite-derived catalysts

\section{Introduction}

Fossil energy is a type of nonrenewable energy with limited reserves and potential to cause environment pollution. Thus, searching for renewable and clean energy resources is becoming urgent. As a clean energy with high heating value, hydrogen energy has aroused extensive attention $[1,2]$. However, the vast majority of hydrogen for human society is produced by further processing fossil fuel at present [3]. To this end, it is imperative to develop a new approach of hydrogen production, with renewable resources as raw materials [4]. The oxygenated compounds gained from biomass pyrolysis, such as alcohols and acids, have been used as raw materials for hydrogen production [4-6]. Hydrogen production from biomass pyrolysis-derived oxygenated compounds is considered environmental and economical [7].

Among those methods for biomass-derived oxygenated compounds reforming, gasification and steam reforming is considered much more appropriate for the process of hydrogen production, due to the merit of minimizing side effects under high pressures and temperatures. Considering the requirement of volatilizing water and multiple reactors or multi-stages to form low levels of $\mathrm{CO}$ in the gas products for steam reforming process, aqueous-phase reforming developed by the Dumesic group (which has advantages of low cost, no requirement of high temperature, and minimal undesirable 
decomposition reactions) is thought to be a more appropriate method for biomass-derived oxygenated compounds reforming $[8,9]$.

The oxygenated molecules from bio-oil have been extensively investigated in recent years $[10,11]$. Among these compounds, ethylene glycol (EG), as the main composition of bio-oil, is considered a renewable and available energy carrier $[12,13]$. Furthermore, ethylene glycol has a similar structural composition to polyols, such as the $\mathrm{C}-\mathrm{C}, \mathrm{C}-\mathrm{H}, \mathrm{C}-\mathrm{O}$, and $\mathrm{H}-\mathrm{O}$ bands; with less carbon bonds, ethylene glycol is an optimum bio-oil model compound for aqueous phase reforming (APR).

In the first reaction step of the ethylene glycol APR process, $\mathrm{C}-\mathrm{C}$ and $\mathrm{C}-\mathrm{H}$ bonds of ethylene glycol were broken to form the surface adsorbed species, such as CO. Then, water-gas shift (WGS) reaction proceeded, and $\mathrm{CO}$ was transformed into $\mathrm{H}_{2}$ and $\mathrm{CO}_{2}$, as shown by Equations (1) and (2):

$$
\begin{gathered}
\mathrm{C}_{2} \mathrm{H}_{6} \mathrm{O}_{2}+\mathrm{H}_{2} \mathrm{O} \rightarrow \mathrm{CO}+\mathrm{H}_{2} \\
\mathrm{CO}+\mathrm{H}_{2} \mathrm{O} \rightarrow \mathrm{CO}_{2}+\mathrm{H}_{2}
\end{gathered}
$$

Various catalysts have been used for APR process, such as Pt, Pd, Ir, or Ru [14,15]. These noble metals present a high activity of hydrogen production; however, their further application is hindered due to the high cost. Therefore, it is necessary to seek APR catalysts with low cost and high activity. Metals of monometallic, bimetallic, or oxides obtained with low cost are ideal catalysts for APR reactions. Layered double hydroxides (LDHs), also known as hydrotalcite-like compounds, have attracted attention due to their outstanding properties as catalyst support, adsorbents, ion-exchange materials, and drug storage-delivery agents. The chemical composition of hydrotalcite-like compounds can be defined as: $\left[\mathrm{M}^{2+}{ }_{(1-\mathrm{x})} \mathrm{M}^{3+}{ }_{\mathrm{x}}(\mathrm{OH})_{2}\right] \times\left[\mathrm{A}^{\mathrm{n}-}\right]_{\mathrm{x} / \mathrm{n}} \times \mathrm{mH}_{2} \mathrm{O}$; where $\mathrm{M}^{2+}$ and $\mathrm{M}^{3+}$ can be used instead of any divalent (typically $\mathrm{Mg}^{2+}, \mathrm{Ni}^{2+}, \mathrm{Mn}^{2+}, \mathrm{Co}^{2+}, \mathrm{Fe}^{2+}, \mathrm{Zn}^{2+}, \mathrm{Cu}^{2+}$ ) and trivalent (typically $\left.\mathrm{Al}^{3+}, \mathrm{Fe}^{3+}, \mathrm{La}^{3+}, \mathrm{Cr}^{3+}, \mathrm{Ga}^{3+}\right)$ metal cations, and $\mathrm{A}^{\mathrm{n}-}$ is a substitutable anion. Thermal decomposition of hydrotalcite-like compounds leads to crystal water loss and removal of interlayer anions and hydroxyl, so that mixed oxides with higher surface area can be obtained $[16,17]$. The mixed oxides after calcination always show high activity owing to their smaller crystal size, basic surface properties, higher surface area, and structure memory effect [18-20]. Catalysts derived from hydrotalcite have been used in the reactions of $\mathrm{H}_{2}$ production, such as steam reforming of alcohols or hydrocarbon; and other reactions like polymerization, aldol condensation, and hydrogenation [21-23].

Ni species which belong to VIII groups have similar properties to noble metals, such as $\mathrm{Pt}$ and Pd. Moreover, nickel species as APR catalysts have advantages, such as high availability and low cost. It was reported that the hydrogen selectivity and catalytic activity were improved when introducing $\mathrm{Sn}$ to Ni/Al hydrotalcite [24]. Meanwhile, the introduction of $\mathrm{Cu}$ can lead to small and well-dispersed particles during the co-precipitation synthesis process of hydrotalcite precursor [25]. Abello et al. found that adding $\mathrm{ZnO}$ to the $\mathrm{Ni} / \mathrm{Al}_{2} \mathrm{O}_{3}$ catalyst could improve the activity of the catalyst and the selectivity of $\mathrm{H}_{2}$ and $\mathrm{CO}_{2}$ during the ethanol steam reforming reaction [26]. Also, hydrotalcite-derived $\mathrm{Ni} / \mathrm{Mg}-\mathrm{Al}$ catalysts exhibited high activity and stability in methane reforming [27].

In this paper, five kinds of hydrotalcite-derived catalysts were prepared by co-precipitation method and a series of transition metals $(\mathrm{Mg}, \mathrm{Cu}, \mathrm{Zn}, \mathrm{Sn}, \mathrm{Mn})$ were added in the synthesis process of $\mathrm{Ni}-\mathrm{Al}$-based hydrotalcite-like precursors. The catalytic performances of hydrotalcite-derived catalysts with different metal compositions in the ethylene glycol APR process were investigated.

\section{Results and Discussion}

\subsection{Catalyst Characterization}

The X-ray diffraction (XRD) patterns of hydrotalcite-like precursors are shown in Figure 1. It can be seen that NMgA, NSnA, NZnA, and NCuA samples exhibited a similar structure. Due to the formation of $\mathrm{SnO}$ at 29.8, 33.2, 50.6, and 57.5 , several special peaks of NSnA hydrotalcite precursors were higher than those of other hydrotalcite precursors. The diffraction peaks appeared at 11.4 (003), 
23.2 (006), 35.4 (102), 38.8 (105), 46.3 (108), 61.9 (110), and 62.1 (113) in the XRD patterns of NMgA, $\mathrm{NSnA}, \mathrm{NZnA}$, and NCuA hydrotalcite-like precursors, which demonstrated that these four samples had well-crystallite hydrotalcite structure and only traces of other crystallite phases existed in these compounds. However, for the Ni/Mn/Al precursor, no hydrotalcite crystalline peak was observed.

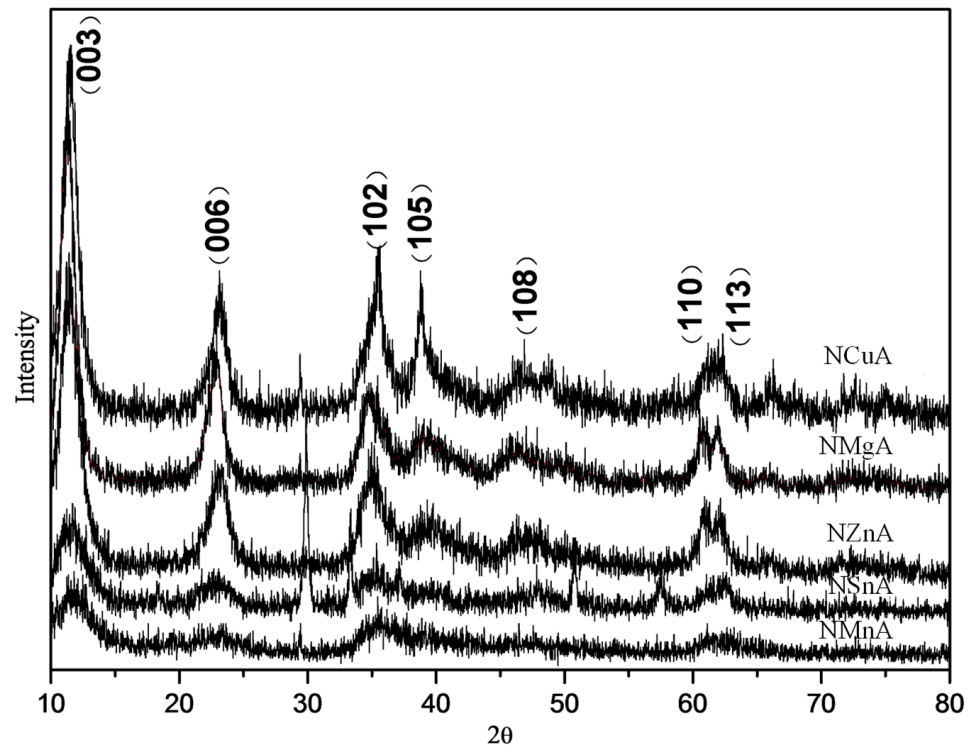

Figure 1. XRD patterns of different precursors derived from hydrotalcite.

As shown in Figure 2, the lamellar structure of hydrotalcite disappeared after calcining at $500{ }^{\circ} \mathrm{C}$, which demonstrated that the hydroxyl of the crystal lattice in the catalysts was dehydrated and the carbonate was decomposed. $\mathrm{NiO}$ and spinel phase appeared in the $\mathrm{NMgA}-\mathrm{C}, \mathrm{NCuA}-\mathrm{C}$, and $\mathrm{NZnA}-\mathrm{C}$ samples after calcination. The formation of a spinel phase in these samples could enhance the interaction between $\mathrm{NiO}, \mathrm{ZnO} / \mathrm{CuO} / \mathrm{MgO}$, and $\mathrm{Al}_{2} \mathrm{O}_{3}$, making the catalysts exhibit higher uniformity and become more beneficial for APR reaction. Due to the formation of $\mathrm{NiO}, \mathrm{Ni}$ species were obtained in the following reduction process, which was the key metal for dissociation of $\mathrm{C}-\mathrm{H}$ and $\mathrm{C}-\mathrm{O}$ bonds during the reforming reaction [28]. A mixture of the rock salt type phase $(\mathrm{NiO})$, wurizite type phase $(\mathrm{ZnO})$, and spinel phase $\left(\mathrm{ZnAl}_{2} \mathrm{O}_{4}\right)$ was formed, as shown in the XRD pattern of NZnA-C catalyst, which is consistent with the results reported by Resini et al. [29]. However, no $\mathrm{Al}_{2} \mathrm{O}_{3}$ phase was observed in the XRD pattern of $\mathrm{NZnA}-\mathrm{C}$, which was probably due to the dispersion of $\mathrm{Al}_{2} \mathrm{O}_{3}$ in $\mathrm{NZnA}-\mathrm{C}$ sample being beyond the limit of detection. The results of XRD pattern showed that rock salt type phase $(\mathrm{NiO})$ and the spinel phase $\left(\mathrm{CuAl}_{2} \mathrm{O}_{4}\right)$ appeared in $\mathrm{NCuAl}-\mathrm{C}$, which is consistent with the results reported by Alejandre [30]. However, $\mathrm{CuO}$ phase was not observed in the NCuA-C sample, which was due to the large amount of $\mathrm{CuNiAl}$ mixed metal oxides that formed after calcination [31]. In these mixed metal oxides, $\mathrm{CuO}, \mathrm{NiO}$, and $\mathrm{Al}_{2} \mathrm{O}_{3}$ were combined through metal-oxygen bonds, and a solid solution with high dispersion of active species was formed. Such a well-distributed structure in the $\mathrm{NCuA}-\mathrm{C}$ sample could enhance the catalytic activity. Meanwhile, the rock salt type of the $\mathrm{Ni}-\mathrm{Mg}-\mathrm{O}$ solid solution was formed in $\mathrm{NMgA}-\mathrm{C}$. In combination with the TPR result of $\mathrm{NMgA}-\mathrm{C}$ samples, it can be speculated that $\mathrm{NiO}$ had a strong interaction with $\mathrm{MgO}$ and/or $\mathrm{Al}_{2} \mathrm{O}_{3}$ in the $\mathrm{NMgA}-\mathrm{C}$ sample, which is consistent with the report by Takehira at al. [32]. As shown in Figure 2, the XRD peaks of $\mathrm{NMgA}-\mathrm{C}$ samples were attributed to the characteristic diffractions of the $\mathrm{Ni}-\mathrm{Mg}-\mathrm{O}$ solid solution, which was formed by incorporating $\mathrm{NiO}$ into the $\mathrm{MgO}$ crystallite phase. $\mathrm{Mn}_{3} \mathrm{O}_{4}$ and $\mathrm{MnO}_{2}$ were shown in the XRD pattern of the NMA-C sample, which is inconsistent with the result reported by Chen et al. [33]. This difference in results might be caused by the difference in the $\mathrm{Ni} / \mathrm{Mn}$ ratio during the preparation processes. As for the $\mathrm{NSnA}-\mathrm{C}$ sample, $\mathrm{SnO}_{2}$ and $\mathrm{Sn}_{3} \mathrm{O}_{4}$ were formed after calcination, but species of $\mathrm{NiO}$ and $\mathrm{Al}_{2} \mathrm{O}_{3}$ were not detected, due to its well dispersion after calcination. 


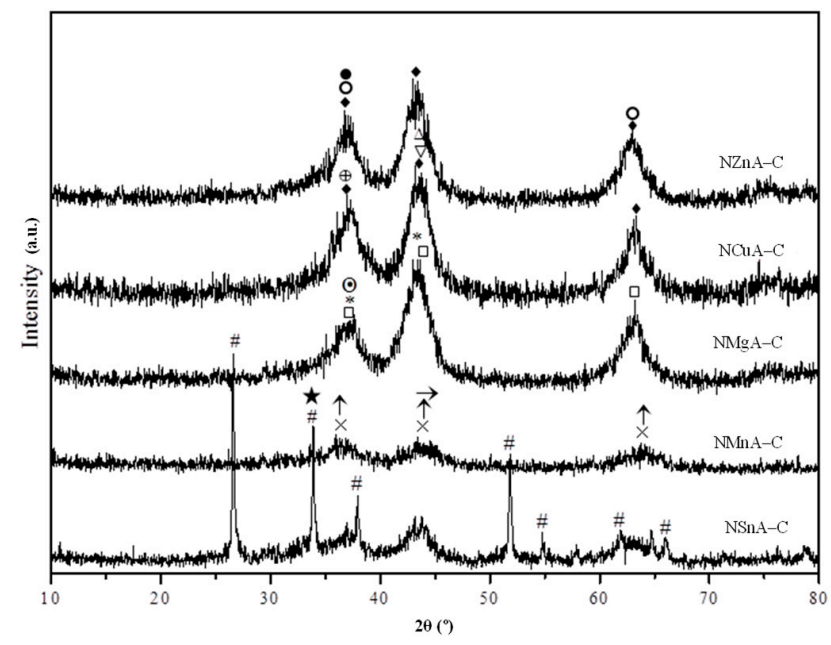

Figure 2. XRD patterns of different calcined catalysts derived from hydrotalcite. $\downarrow$ : $\mathrm{NiO} ; \bigcirc: \mathrm{ZnO}$; $\mathrm{ZnAl}_{2} \mathrm{O}_{4} ; \bigoplus: \mathrm{CuAl}_{2} \mathrm{O}_{4} ; \nabla: \mathrm{AlNi}_{3} ; \Delta: \mathrm{AlCu}_{4} ; \square: \mathrm{MgAl}_{2} \mathrm{O}_{4} ;{ }^{*}: \mathrm{Al}_{2} \mathrm{Mg} ; \odot: \mathrm{Mg}_{2} \mathrm{Ni} ; \times: \mathrm{Al}_{2} \mathrm{O}_{3} ; \uparrow: \mathrm{Mn}_{3} \mathrm{O}_{4}$; $\rightarrow: \mathrm{MnO}_{2} ; \#: \mathrm{SnO}_{2} ; \star: \mathrm{Sn}_{3} \mathrm{O}_{4}$.

The XRD patterns of reduced multi-metal oxides are as shown in Figure 3. The nickel oxide was almost reduced to $\mathrm{Ni}\left(39.08,46.60\right.$, and $\left.70.91^{\circ}\right)$ in all five samples [34]. However, several characteristic crystals were also formed, such as the $\mathrm{NiCu}$ and $\mathrm{AlNi}_{3}$ alloy in the reduced catalyst of $\mathrm{NCuA}-\mathrm{R}$. Spinel was not detected, which was due to copper preventing its formation or growth during the process of calcination. In addition, the presence of copper strongly influenced the dispersion of $\mathrm{Ni}$ on the catalyst and inhibited $\mathrm{NiO}$ from forming nickel alumination [35]. Likewise, $\mathrm{AlNi}_{3}$ alloy also appeared in NSnA-R, but there was still some $\mathrm{SnO}$ present in NSnA-R, which is consistent with the $\mathrm{H}_{2}$-TPR result. AlNi alloy appeared in both $\mathrm{NZnA-R}$ and NMgA-R samples, and part of ZnO still existed in the NZnA-R sample, as shown in the XRD pattern. This was because the reduction of $\mathrm{ZnO}$ required higher temperatures, over $500{ }^{\circ} \mathrm{C}$. Meanwhile, $\mathrm{ZnO}$ can be easily transformed to $\mathrm{Zn}(\mathrm{OH})_{2}$ under the $\mathrm{H}_{2}$ atmosphere and then dehydrated to $\mathrm{ZnO}[36,37] . \mathrm{MgAl}_{2} \mathrm{O}_{4}$ still existed and no $\mathrm{Mg}^{0}$ was observed in the $\mathrm{NMgA}-\mathrm{R}$ sample, which indicated that spinel was difficult to reduce at $500{ }^{\circ} \mathrm{C} . \mathrm{AlNi}_{3}$, $\mathrm{Al}_{0.9} \mathrm{Ni}_{4.22}$, and $\mathrm{Al}_{7} \mathrm{Mn}_{3} \mathrm{Ni}_{30}$ phases appeared in the XRD pattern of $\mathrm{NMnA}-\mathrm{R}$ sample.

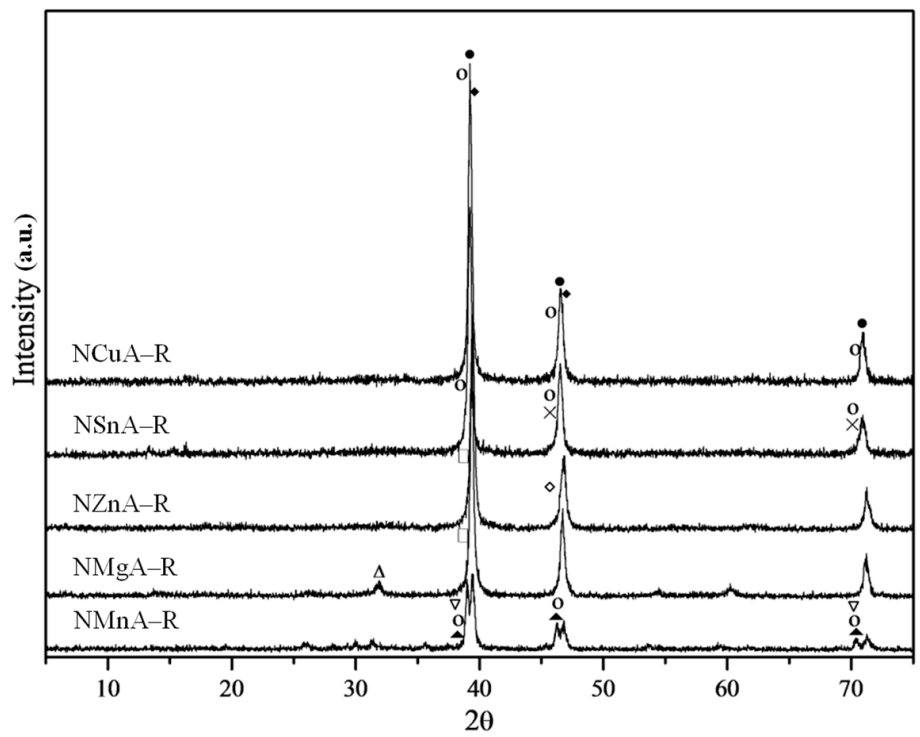

Figure 3. XRD patterns of different hydrotalcite-derived catalysts after reduction. ४: $\mathrm{NiCu} ; \times: \mathrm{SnO} ; \square: \mathrm{AlNi} ; \diamond: \mathrm{ZnO} ; \triangle: \mathrm{MgAl}_{2} \mathrm{O}_{4} ; \nabla: \mathrm{Al}_{0.9} \mathrm{Ni}_{4.22} ; \mathbf{\Delta}: \mathrm{Al}_{7} \mathrm{Mn}_{3} \mathrm{Ni}_{30}$. 
$\mathrm{H}_{2}$-TPR spectra of different hydrotalcite-derived Ni-Al calcined catalysts are as shown in Figure 4 . Two reductive peaks were shown in NCuA-C; one appeared between 188 and $281{ }^{\circ} \mathrm{C}$, and the other appeared between 281 and $385^{\circ} \mathrm{C}$. The peak that appeared at the lower temperature was attributed to the reduction of $\mathrm{CuO}$ to $\mathrm{Cu}^{0}$, which suggested that traces of well dispersed $\mathrm{CuO}$ existed in calcined $\mathrm{Ni} / \mathrm{Cu} / \mathrm{Al}$ samples [35,37]. Moreover, the peak at the higher temperature was ascribed to the reduction of $\mathrm{Ni}^{2+} \rightarrow \mathrm{Ni}^{0}$ [37]. Similarly, the reduction peak of $\mathrm{Ni}^{2+}$ to $\mathrm{Ni}^{0}$ occurred between $411^{\circ} \mathrm{C}$ and $793{ }^{\circ} \mathrm{C}$ for the $\mathrm{NMgA}-\mathrm{C}$ sample. The introduction of $\mathrm{Mg}$ species broadened the scope of the reduction peaks in the $\mathrm{NMgA}-\mathrm{C}$ sample and made it difficult for the $\mathrm{Ni}^{2+}$ species to be reduced to $\mathrm{Ni}^{0}[38,39]$. The increase of reduction temperature for $\mathrm{Ni}^{2+}$ was due to the formation of a $\mathrm{NiO}-\mathrm{MgO}$ solid solution, by which $\mathrm{Ni}^{2+}$ ions were stabilized. Two reductive peaks appeared in the TPR profile of the NMA-C sample. The peak at $252{ }^{\circ} \mathrm{C}$ was probably attributed to the reduction of $\mathrm{MnO}_{2}$, to $\mathrm{Mn}_{2} \mathrm{O}_{3}$ or $\mathrm{Mn}_{3} \mathrm{O}_{4}$. The peak appearing at the higher temperature between 343 and $690^{\circ} \mathrm{C}$ was ascribed to the reduction of $\mathrm{Ni}^{2+}$ to $\mathrm{Ni}^{0}$ with a shoulder peak [33]. There were also two reductive peaks in the TPR profile of the calcined NSnA-C sample. The first peak appearing within the range of 460 to $525^{\circ} \mathrm{C}$ was attributed to the reduction of $\mathrm{Ni}^{2+}$, while that appearing between 525 and $637^{\circ} \mathrm{C}$ was mainly ascribed to the reduction of $\mathrm{NiSnAl}(\mathrm{O})$ oxides [24,40]. The broad peak of calcined NZnA-C appearing between 333 and $813^{\circ} \mathrm{C}$ can probably be attributed to the reduction of $\mathrm{Ni}^{2+}$ to $\mathrm{Ni}^{0}$. The existing $\mathrm{Zn}$ cation made the reduction of $\mathrm{Ni}^{2+}$ shift to a higher temperature. The reductive peak appearing at $950{ }^{\circ} \mathrm{C}$ was attributed to the reduction of $\mathrm{Zn}^{2+}$ in the NZnA-C sample.

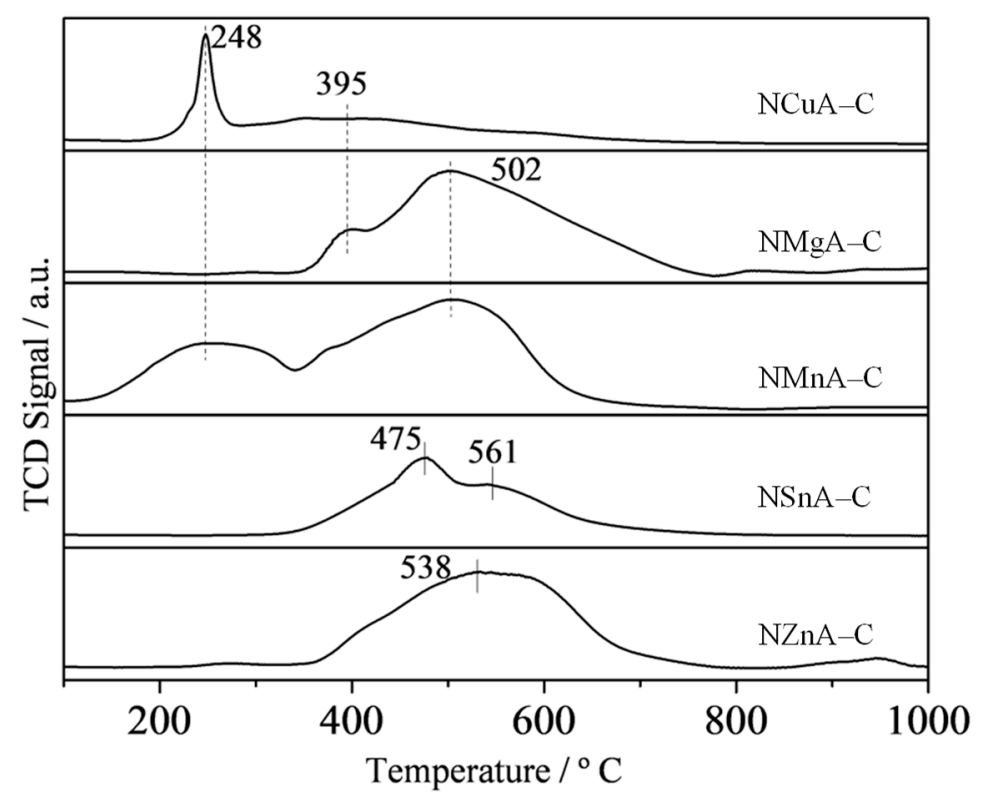

Figure 4. Temperature-programmed reduction (TPR) profiles of different calcined catalysts derived from hydrotalcite.

Specific surface area, pore volume, and pore diameter of all the samples obtained from $\mathrm{N}_{2}$ physical adsorption are listed in Table 1. Among the calcined samples, $\mathrm{NZnA-C}$ had the highest specific surface area of $149 \mathrm{~m}^{2} / \mathrm{g}$, and NSnA-C had the lowest specific surface area of $80 \mathrm{~m}^{2} / \mathrm{g}$. NMgA-C had the largest pore volume of $0.319 \mathrm{~cm}^{3} / \mathrm{g}$. After reduction, the specific surface areas and pore volumes were decreased significantly for NZnA-R, NCuA-R, NSnA-R, and NMnA-R, but the specific surface area and pore volume of NMgA-R decreased slightly. The pore sizes were decreased significantly for all the samples after reduction. The NMgA-R sample showed the highest specific surface area of $110 \mathrm{~m}^{2} / \mathrm{g}$, while NZnA-R exhibited the largest pore volume of $0.126 \mathrm{~cm}^{3} / \mathrm{g}$. 
Table 1. Textural characteristics of the calcined and reduced catalysts derived from hydrotalcite.

\begin{tabular}{cccc}
\hline Sample & BET $\left.\mathbf{( \mathbf { m } ^ { 2 }} / \mathbf{g}\right)$ & Pore Volume $\left.\mathbf{( \mathbf { c m } ^ { 3 }} / \mathbf{g}\right)$ & Pore Size $\mathbf{( n m )}$ \\
\hline NCuA-C & 120 & 0.149 & 23.6 \\
NCuA-R & 43 & 0.108 & 16.9 \\
NZnA-C & 149 & 0.246 & 39.9 \\
NZnA-R & 70 & 0.126 & 36.6 \\
NMgA-C & 138 & 0.319 & 53.3 \\
NMgA-R & 110 & 0.115 & 18.8 \\
NMA-C & 128 & 0.182 & 21.7 \\
NMnA-R & 23 & 0.052 & 18.9 \\
NSnA-C & 80 & 0.151 & 25.8 \\
NSnA-R & 31 & 0.079 & 18.9 \\
\hline
\end{tabular}

\subsection{Catalytic Performance}

The APR reaction results over hydrotalcite-derived catalysts are as shown in Figures 5 and 6. Through comparing the reaction results over hydrotalcite-derived catalysts before and after reduction, it was found that the selectivity and yield of $\mathrm{H}_{2}$ were higher when using reduced hydrotalcite-derived catalysts, except for in NMgA-C and NMgA-R. Meanwhile, as shown in Table 1, the conversions of ethylene glycol are generally higher than $90 \%$.

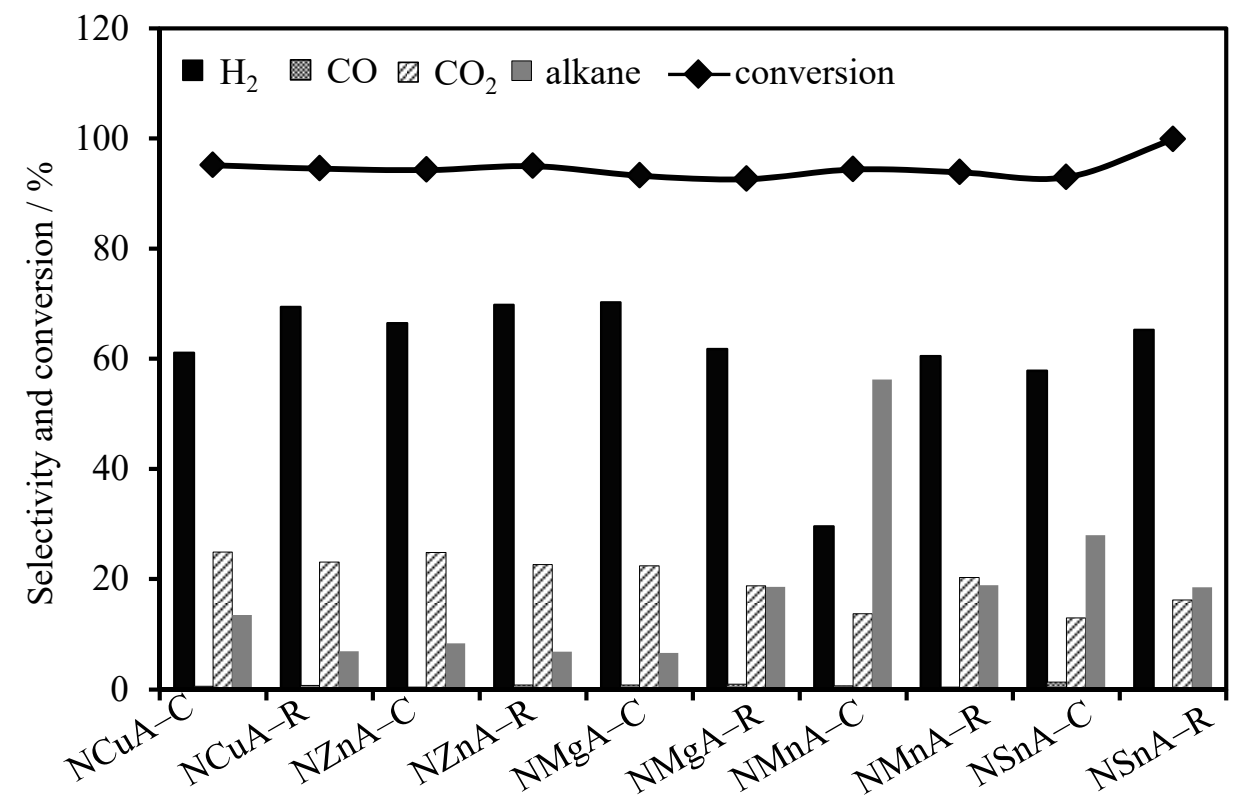

Catalysts

Figure 5. The selectivity of $\mathrm{H}_{2}, \mathrm{CO}, \mathrm{CO}_{2}$, and alkane in the gas products after aqueous-phase reforming (APR) of ethylene glycol over hydrotalcite-derived catalysts. 


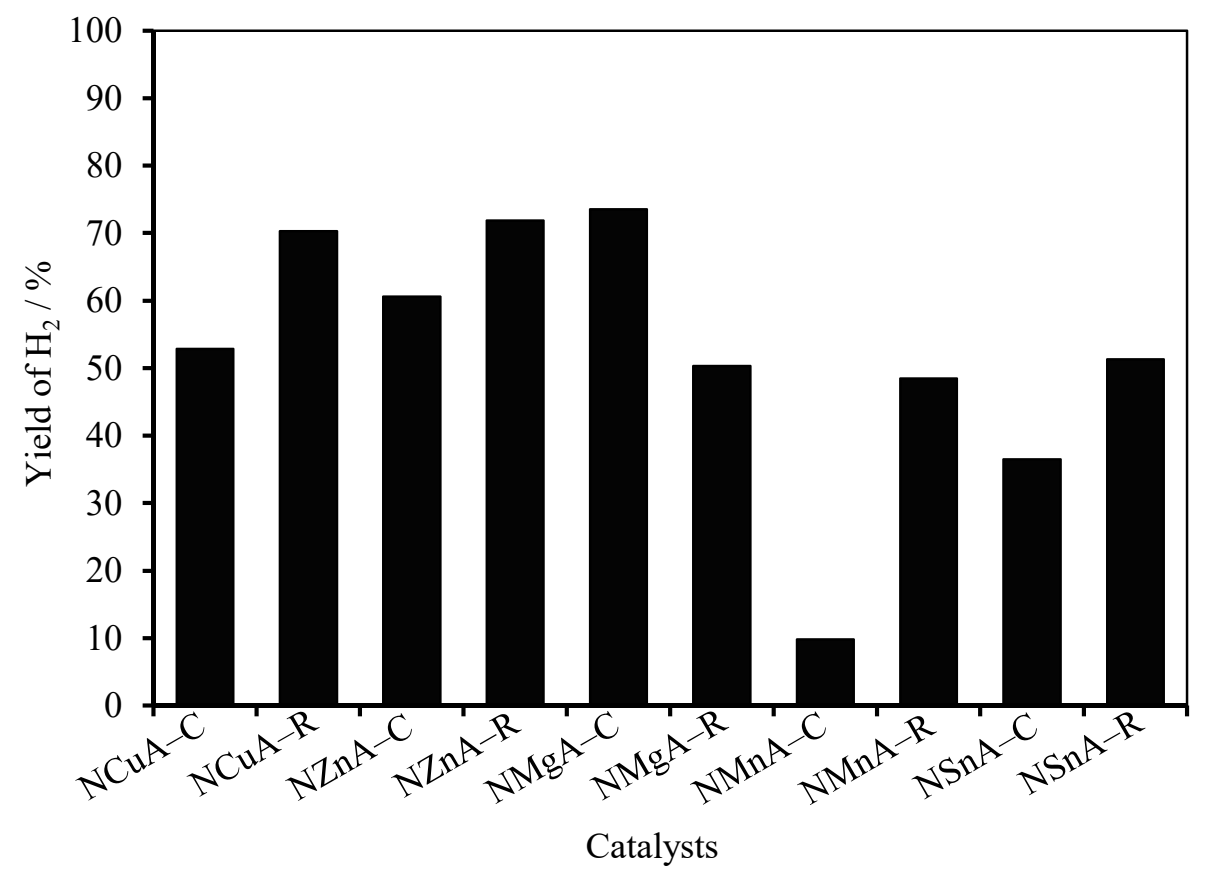

Figure 6. $\mathrm{H}_{2}$ yield for ethylene glycol APR over hydrotalcite-derived catalysts.

Based on the results of gas chromatograph (GC), it can be known that $\mathrm{H}_{2}, \mathrm{CH}_{4}, \mathrm{CO}, \mathrm{CO}_{2}$, and $\mathrm{C}_{2} \mathrm{H}_{6}$ were the main gas products for the APR reaction. The selectivity of $\mathrm{H}_{2}$ ranged from $29.5 \%$ to $70.3 \%$. The highest selectivity of $\mathrm{H}_{2}$ was obtained by $\mathrm{NMgA}-\mathrm{C}$. It can be deduced that adding magnesium to the $\mathrm{Ni}-\mathrm{Al}$ hydrotalcite-derived catalysts could enhance the selectivity of $\mathrm{H}_{2}$. In addition, strong interaction was formed between $\mathrm{Ni}$ and $\mathrm{Mg}(\mathrm{Al}) \mathrm{O}$, which is in favor of transforming electrons from the $\mathrm{Mg}(\mathrm{Al}) \mathrm{O}$ supporter into $\mathrm{Ni}$ species. Thus, the electronegativity of the active $\mathrm{Ni}$ species increased, and the dehydration probability of ethylene glycol was further decreased [41]. Then, the selectivity of $\mathrm{H}_{2}$ was improved in APR reaction. The lowest selectivity of $\mathrm{H}_{2}$ was obtained by the NMA-C catalyst, and only weak catalytic activity was shown during the APR reaction. As shown in Figure 5, NCuA-R/C and NZnA-R/C as catalysts, showed excellent catalytic performance; and the selectivity of $\mathrm{H}_{2}$ over these catalysts were higher than that when using NSnA-R/C and NMnA-R/C as catalysts.

After APR reaction, the selectivity of alkanes in gas ranged between $6.6 \%$ and $56.3 \%$. The highest selectivity of alkanes, as well as lower selectivities of $\mathrm{H}_{2}, \mathrm{CO}$ and $\mathrm{CO}_{2}$, were obtained when using NMA-C as catalyst. The higher selectivity of hydrogen and lower activity for methanation over hydrotalcite-derived catalysts may be caused by well dispersion of Ni species, which was more suitable for $\mathrm{CO}$ dissociation, resulting in high $\mathrm{H}_{2}$ selectivity and low alkane formation. This speculation is consistent with the report of Dumesic group who added Sn to Ni catalysts [34,42,43].

The yields of $\mathrm{H}_{2}$ ranged between $9.8 \%$ and $73.5 \%$, and the highest yield of $\mathrm{H}_{2}$ was obtained when using NMgA-C as catalyst during the APR process. The catalytic activities of hydrotalcite-derived catalysts for $\mathrm{H}_{2}$ production can be ranked in the order of: $\mathrm{NMgA}-\mathrm{C}>\mathrm{NZnA}-\mathrm{R}>\mathrm{NCuA}-\mathrm{R}>\mathrm{NZnA}-\mathrm{C}$ $>\mathrm{NCuA}-\mathrm{C}>\mathrm{NMgA}-\mathrm{R}>\mathrm{NSnA}-\mathrm{R}>\mathrm{NMnA}-\mathrm{R}>\mathrm{NSnA}-\mathrm{C}>\mathrm{NMA}-\mathrm{C}$. APR reaction over the reduced hydrotalcite-derived catalysts could produce a higher yield of $\mathrm{H}_{2}$ than APR reaction over the calcined hydrotalcite-derived catalysts, except for $\mathrm{NMgA}-\mathrm{C}$ and $\mathrm{NMgA}-\mathrm{R}$. It can be deduced that part of the $\mathrm{H}_{2}$ in products resulted from the water gas shift reaction, and part of the $\mathrm{H}_{2} \mathrm{O}$ was transformed into $\mathrm{H}_{2}$ under these reaction conditions due to the presence of Ni species in catalysts.

Hydrotalcite-derived catalysts exhibited excellent catalytic performance in terms of $\mathrm{H}_{2}$ production, indicating that the hydrotalcite-derived catalysts have great potential for application in APR reactions. It was also found that the use of basic supporters, such as $\mathrm{MgO}, \mathrm{ZnO}$, and $\mathrm{CuO}$, can enhance hydrogen production, because it has been reported that the basic supporter in hydrotalcite-derived catalysts can decrease the coke formation, and thus, enhance the stability of a catalyst [44-46]. 


\section{Experimental Methods}

\subsection{Catalyst Preparation}

Hydrotalcite-like compounds were prepared by co-precipitation method at room temperature. The detailed synthesis processes were as follows: Firstly, $3.14 \mathrm{~mol}$ of nickel nitrate hexahydrate, $0.69 \mathrm{~mol}$ of aluminum hydrate nitrate, and certain amounts of $\mathrm{Mg} / \mathrm{Cu} / \mathrm{Zn} / \mathrm{Sn} / \mathrm{Mn}$ in the form of nitrate were dissolved in $50 \mathrm{~mL}$ of deionized water while being vigorously stirred, resulting in solution $\mathrm{A}$. The molar ratio of $\mathrm{Al}$ to the total metals was 0.25 in solution $\mathrm{A}$. A mixture of $0.518 \mathrm{~mol}$ of $\mathrm{Na}_{2} \mathrm{CO}_{3}$ $\left(\mathrm{CO}_{3}{ }^{2-} / \mathrm{Al}^{3+}=0.375\right)$ and $8.7 \mathrm{~mol}$ of $\mathrm{NaOH}\left(\mathrm{OH}^{-} / \mathrm{Al}^{3+}=6.3\right)$ were dissolved in $50 \mathrm{~mL}$ of deionized water, resulting in solution $\mathrm{B}$. Then, solution A was added dropwise into solution $\mathrm{B}$ while being vigorously stirred. Afterwards, the obtained gel was aged under a constant $\mathrm{pH}$ of 13 for $18 \mathrm{~h}$ at $80^{\circ} \mathrm{C}$. The obtained solid was filtered and washed with distilled water $\left(90^{\circ} \mathrm{C}\right)$ until the $\mathrm{pH}$ of the filtrate was adjusted to 7 . Finally, the obtained hydrotalcite precursors were put into an oven and dried at $100{ }^{\circ} \mathrm{C}$ for $12 \mathrm{~h}$. In this paper, in order to make it easier to understand, the hydrotalcite-like compounds of $\mathrm{Ni} / \mathrm{Mg} / \mathrm{Al}, \mathrm{Ni} / \mathrm{Cu} / \mathrm{Al}, \mathrm{Ni} / \mathrm{Zn} / \mathrm{Al}, \mathrm{Ni} / \mathrm{Sn} / \mathrm{Al}$, and $\mathrm{Ni} / \mathrm{Mn} / \mathrm{Al}$ were denoted as NMgA, NCuA, NZnA, NSnA, and NMnA for short, respectively.

The hydrotalcite-derived multi-metal mixed oxides were obtained by calcination of the above obtained hydrotalcite-like compounds at $500{ }^{\circ} \mathrm{C}$ for $2 \mathrm{~h}$ under dry air, at a heating rate of $10^{\circ} \mathrm{C} / \mathrm{min}$. The samples after calcination were denoted as NMgA-C, NCuA-C, NZnA-C, NSnA-C, and NMA-C for short in this paper, respectively.

Simultaneously, part of the decomposed hydrotalcite-derived samples, including $\mathrm{NMgA}-\mathrm{C}$, $\mathrm{NCuA}-\mathrm{C}, \mathrm{NZnA}-\mathrm{C}, \mathrm{NSnA}-\mathrm{C}$, and NMA-C, were further reduced under a hydrogen and nitrogen atmosphere with a $\mathrm{H}_{2}$ to $\mathrm{N}_{2}$ ratio of 3:7. The reduction step was proceeded at $500{ }^{\circ} \mathrm{C}$ for $4 \mathrm{~h}$ with a heating rate of $10^{\circ} \mathrm{C} / \mathrm{min}$, and the obtained samples were denoted as NMgA-R, NCuA-R, NZnA-R, NSnA-R, and NMnA-R for short in this paper.

\subsection{Catalyst Characterization}

X-ray diffraction was conducted on a X-ray diffractometer (Bruker, D8 Advance, Germany) with the scanning scope of $2 \theta$ angle ranging from 10 to $90^{\circ}$. Scherrer Equation was introduced in this paper to calculate the crystallite size of samples. $\mathrm{H}_{2}$-temperature programmed reduction $\left(\mathrm{H}_{2}-\mathrm{TPR}\right)$ was performed using an Autosorb-iQ-C-TCD-MS instrument (Quantachrome, America). In order to remove the surface contaminants, $50 \mathrm{mg}$ of the catalyst was charged in a U-shaped quartz cell and pretreated at $300{ }^{\circ} \mathrm{C}$ in a pure $\mathrm{N}_{2}$ atmosphere for $3 \mathrm{~h}$. Finally, the sample in the U-shaped quartz cell was kept under $95 \% \mathrm{H}_{2} / \mathrm{Ar}$ and heated from room temperature to $1000{ }^{\circ} \mathrm{C}$ at a rate of $10^{\circ} \mathrm{C} / \mathrm{min}$. The consumption of $\mathrm{H}_{2}$ was quantified by a thermal conductivity detector. The physical properties, including Brunauer-Emmett-Teller (BET) specific area, pore volume, and pore size, were detected by $\mathrm{N}_{2}$ sorption at $-196^{\circ} \mathrm{C}$ using an Autosorb-iQ-C-TCD-MS instrument. Before analysis, samples needed to outgas at $150{ }^{\circ} \mathrm{C}$ under $\mathrm{N}_{2}$ gas flow for $6 \mathrm{~h}$. Data on the surface area was obtained by using the classic BET method, and Barret-Joyner-Halenda (BJH) method were applied to evaluate the pore properties of samples.

\subsection{Catalytic Tests}

The test for catalytic performance of $\mathrm{Ni}-\mathrm{Al}$ based hydrotalcite-derived catalysts in ethylene glycol APR was conducted in an autoclave. Before reaction, $50 \mathrm{~mL}$ of $20 \mathrm{wt} \%$ ethylene glycol-water solution was put in the autoclave. Then, $100 \mathrm{mg}$ of hydrotalcite-derived catalyst was put into the autoclave. After that, nitrogen was introduced into the autoclave, and the autoclave was flushed three times to remove the residue air. Then, the reaction was carried out at $225^{\circ} \mathrm{C}$ under nitrogen pressure of $2.6 \mathrm{MPa}$ for $2.5 \mathrm{~h}$ [47]. After reaction, the gas phases were collected using a gas collecting bag and detected using gas chromatography (Beifen GC-3420A, China) equipped with a Porapak Q column of $3 \mathrm{~m}$ and a $5 \mathrm{~A}$ molecular sieve. The selectivity of these products was calculated under the condition of ignoring 
water. The liquid phase that resulted from the reaction was detected using the apparatus of Agilent 7890A (GC, 60m DB-Wax capillary column, America).

The conversion of ethylene glycol and selectivity of $\mathrm{H}_{2}$ and alkane were calculated according to the following equation [47].

The conversion of ethylene glycol is defined as follows:

Conversion of ethylene glycol $(\%)=\frac{\text { moles of ethylene glycol in the feedstock }- \text { moles of ethylene glycol in products }}{\text { moles of ethylene glycol in the feedstock }} \times 100$

The selectivity of gaseous products is expressed as:

$$
\text { Selectivity of gas product }(\%)=\frac{\text { The mole of the product in gas products }}{\text { The total mole of gas products }} \times 100
$$

The hydrogen yield is defined as follows:

$$
\mathrm{H}_{2} \text { yield }(\%)=\frac{\text { The mole of } \mathrm{H}_{2} \text { in gas products }}{\text { The mole of ethylene glycol as reactant } \times 5} \times 100
$$

\section{Conclusions}

Hydrotalcite-derived catalysts were obtained by co-precipitation method and post-treatment. All of the hydrotalcite-like precursors showed hydrotalcite crystalloids with a layered double structure, except for the NMnA sample. Due to the instability of Mn cations, non-hydrotalcite crystalloid structure of the NMnA precursor was formed. Hydrotalcite-derived samples in the form of mixed metal oxides were obtained after calcination. By introducing $\mathrm{Zn}, \mathrm{Mg}$, and $\mathrm{Cu}$ metal species into Ni-Al based hydrotalcite-derived catalysts, a more uniform structure was formed, and $\mathrm{NiO}$ and spinel phase were generated after calcination. In the APR reaction, the yield of $\mathrm{H}_{2}$ was $73.5 \%, 70.3 \%$, and $71.9 \%$ when using $\mathrm{NMgA}-\mathrm{C}, \mathrm{NCuA}-\mathrm{R}$, and NZnA-R as catalysts, respectively. High conversion $(>90 \%)$ of ethylene glycol was obtained over the hydrotalcite-derived catalysts. The optimum selectivity of $\mathrm{H}_{2}$ was obtained by APR reaction over $\mathrm{NMgA}-\mathrm{C}$. The formation of $\mathrm{MgO}$ made both nickel and aluminum oxides well dispersed after calcination, which enhanced hydrogen reforming during the APR reaction over $\mathrm{NMgA}-\mathrm{C}$, and thereby improving the selectivity of hydrogen.

Author Contributions: Writing-Original draft preparation and review\& editing, J.Z.; Data Curation \& Methodology, N.X. All authors have read and agreed to the published version of the manuscript.

Funding: This research was funded by the National Natural Science Foundation of China through a project grant (grant number 41502131), the Guangdong Provincial Key Laboratory of New and Renewable Energy Research and Development (Y807s81001), the Fundamental Research Funds for the Central Universities (18CX02101A), and the National Science and Technology Major Project (2016ZX05014-004-007).

Acknowledgments: The authors acknowledge Guangdong Provincial Key Laboratory of New and Renewable Energy Research and Development for supporting this work.

Conflicts of Interest: The authors declare that they have no competing interests.

\section{References}

1. Kumar, A.; Singh, R.; Sinha, A.S.K. Catalyst modification strategies to enhance the catalyst activity and stability during steam reforming of acetic acid for hydrogen production. Int. J. Hydrog. Energy 2019, 44, 12983-13010. [CrossRef]

2. Sharma, K. Carbohydrate-to-hydrogen production technologies: A mini-review. Renew. Sustain. Energy Rev. 2019, 105, 138-143. [CrossRef]

3. Dunn, S. Hydrogen futures: Toward a sustainable energy system. Int. J. Hydrog. Energy 2002, 27, $235-264$. [CrossRef]

4. Sanchez, N.; Ruiz, R.Y.; Cifuentes, B.; Cobo, M. Controlling sugarcane press-mud fermentation to increase bioethanol steam reforming for hydrogen production. Waste Manag. (N.Y.) 2019, 98, 1-13. [CrossRef] 
5. Mei, D.; Liu, S.; Wang, Y.; Yang, H.; Bo, Z.; Tu, X. Enhanced reforming of mixed biomass tar model compounds using a hybrid gliding arc plasma catalytic process. Catal. Today 2019, 337, 225-233. [CrossRef]

6. Chen, S.; Liang, S.; Wu, B.; Lan, Z.; Guo, Z.; Kobayashi, H.; Yan, X.; Li, R. Ultrasmall Silver Clusters Stabilized on $\mathrm{MgO}$ for Robust Oxygen-Promoted Hydrogen Production from Formaldehyde Reforming. ACS Appl. Mater. Interfaces 2019, 11, 33946-33954. [CrossRef]

7. Wang, Y.; Wang, C.; Chen, M.; Tang, Z.; Yang, Z.; Hu, J.; Zhang, H. Hydrogen production from steam reforming ethanol over Ni/attapulgite catalysts-Part I: Effect of nickel content. Fuel Process. Technol. 2019, 192, 227-238. [CrossRef]

8. Borowiecki, T.; Cichy, M.; Kowalik, P. Aqueous phase reforming of biomass. Przem. Chem. 2018, 97, 522-538.

9. Vaidya, P.D.; Lopez-Sanchez, J.A. Review of Hydrogen Production by Catalytic Aqueous-Phase Reforming. Chemistryselect 2017, 2, 6563-6576. [CrossRef]

10. Fu, P.; Zhang, A.; Luo, S.; Yi, W.; Hu, S.; Zhang, Y. Catalytic Steam Reforming of Biomass-Derived Acetic Acid over Two Supported Ni Catalysts for Hydrogen-Rich Syngas Production. Acs Omega 2019, 4, 13585-13593. [CrossRef]

11. Zhang, Z.; Hu, X.; Zhang, L.; Yang, Y.; Li, Q.; Fan, H.; Liu, Q.; Wei, T.; Li, C.-Z. Steam reforming of guaiacol over Ni/Al2O3 and Ni/SBA-15: Impacts of support on catalytic behaviors of nickel and properties of coke. Fuel Process. Technol. 2019, 191, 138-151. [CrossRef]

12. Larimi, A.; Khorasheh, F. Renewable hydrogen production by ethylene glycol steam reforming over Al2O3 supported Ni-Pt bimetallic nano-catalysts. Renew. Energy 2018, 128, 188-199. [CrossRef]

13. Gu, G.H.; Wittreich, G.R.; Vlachos, D.G. Microkinetic modeling of aqueous phase biomass conversion:Application to ethylene glycol reforming. Chem. Eng. Sci. 2019, 197, 415-418. [CrossRef]

14. Kwak, B.S.; Kim, J.; Kang, M. Hydrogen production from ethanol steam reforming over core-shell structured $\mathrm{NiOxOy-}$-, FexOy-, and CoxOy-Pd catalysts. Int. J. Hydrog. Energy 2010, 35, 11829-11843. [CrossRef]

15. Palmeri, N.; Cavallaro, S.; Chiodo, V.; Freni, S.; Frusteri, F.; Barta, J.C.J. Hydrogen production from ethanol on $\mathrm{Rh} / \mathrm{MgO}$ based catalysts the influence of rhodium precursor on catalytic performance. Int. J. Hydrog. Energy 2007, 32, 3335-3342. [CrossRef]

16. Kloprogge, J.T.; Hickey, L.; Frost, R.L. Heating stage Raman and infrared emission spectroscopic study of the dehydroxylation of synthetic Mg-hydrotalcite. Appl. Clay Sci. 2001, 18, 37-49. [CrossRef]

17. Mokhtar, M.; Inayat, A.; Ofili, J.; Schwieger, W. Thermal decomposition, gas phase hydration and liquid phase reconstruction in the system $\mathrm{Mg} / \mathrm{Al}$ hydrotalcite/mixed oxide: A comparative study. Appl. Clay Sci. 2010, 50, 176-181. [CrossRef]

18. Basile, F.; Benito, P.; Fornasari, G.; Vaccari, A. Hydrotalcite-type precursors of active catalysts for hydrogen production. Appl. Clay Sci. 2010, 48, 250-259. [CrossRef]

19. Zhou, C.H. Emerging trends and challenges in synthetic clay-based materials and layered double hydroxides Preface. Appl. Clay Sci. 2010, 48, 1-4. [CrossRef]

20. Zhou, C.H. Clay mineral-based catalysts and catalysis Preface. Appl. Clay Sci. 2011, 53, 85-86. [CrossRef]

21. Sels, B.F.; De Vos, D.E.; Jacobs, P.A. Hydrotalcite-like anionic clays in catalytic organic reactions. Catal. Rev. -Sci. Eng. 2001, 43, 443-488. [CrossRef]

22. Kannan, S. Catalytic applications of hydrotalcite-like materials and their derived forms. Catal. Surv. Asia 2006, 10, 117-137. [CrossRef]

23. Busca, G.; Montanari, T.; Resini, C.; Ramis, G.; Costantino, U. Hydrogen from alcohols: IR and flow reactor studies. Catal. Today 2009, 143, 2-8. [CrossRef]

24. Pan, G.; Ni, Z.; Cao, F.; Li, X. Hydrogen production from aqueous-phase reforming of ethylene glycol over $\mathrm{Ni} / \mathrm{Sn} / \mathrm{Al}$ hydrotalcite derived catalysts. Appl. Clay Sci. 2012, 58, 108-113. [CrossRef]

25. Barrabes, N.; Garrido, M.A.; Frare, A.; Monzon, A.; Tichit, D. Pt-MgZnCuAl hydrotalcite-derived catalysts in the reduction of nitrates using continuous and batch reactors. Catal. Today 2011, 175, 328-337. [CrossRef]

26. Barroso, M.N.; Gomez, M.F.; Arrúa, L.A.; Abello, M.C. Hydrogen production by ethanol reforming over NiZnAl catalysts. Appl. Catal. A Gen. 2006, 304, 116-123. [CrossRef]

27. Ohi, T.; Miyata, T.; Li, D.; Shishido, T.; Kawabata, T.; Sano, T.; Takehira, K. Sustainability of Ni loaded Mg-Al mixed oxide catalyst in daily startup and shutdown operations of $\mathrm{CH} 4$ steam reforming. Appl. Catal. A: Gen. 2006, 308, 194-203. [CrossRef] 
28. Das, S.; Ashok, J.; Bian, Z.; Dewangan, N.; Wai, M.H.; Du, Y.; Borgna, A.; Hidajat, K.; Kawi, S. Silica-Ceria sandwiched Ni core-shell catalyst for low temperature dry reforming of biogas: Coke resistance and mechanistic insights. Appl. Catal. B Environ. 2018, 230, 220-236. [CrossRef]

29. Resini, C.; Montanari, T.; Barattini, L.; Ramis, G.; Busca, G.; Presto, S.; Riani, P.; Marazza, R.; Sisani, M.; Marmottini, F.; et al. Hydrogen production by ethanol steam reforming over Ni catalysts derived from hydrotalcite-like precursors: Catalyst characterization, catalytic activity and reaction path. Appl. Catal. A-Gen. 2009, 355, 83-93. [CrossRef]

30. Alejandre, A.; Medina, F.; Rodriguez, X.; Salagre, P.; Cesteros, Y.; Sueiras, J.E. Cu/Ni/Al layered double hydroxides as precursors of catalysts for the wet air oxidation of phenol aqueous solutions. Appl. Catal. B Environ. 2001, 30, 195-207. [CrossRef]

31. Gao, J.; Sun, Y.; Gu, N.; Wu, H.; Zhao, W.; Wang, K. Treatment of Phenol Wastewater by ClO2 in the Presence of CuNiAl Complex Metal Oxide as Catalyst. Fine Chem. 2012, 29, 491-494, 498.

32. Takehira, K.; Shishido, T.; Wang, P.; Kosaka, T.; Takaki, K. Autothermal reforming of CH4 over supported Ni catalysts prepared from Mg-Al hydrotalcite-like anionic clay. J. Catal. 2004, 221, 43-54. [CrossRef]

33. Chen, A.M.; Xu, H.L.; Yue, Y.H.; Shen, W.; Hua, W.M.; Gao, Z. M-Mn-Al hydrotalcite-like compounds as precursors for methyl benzoate hydrogenation catalysts. Ind. Eng. Chem. Res. 2004, 43, 6409-6415. [CrossRef]

34. Huber, G.W.; Shabaker, J.W.; Dumesic, J.A. Raney Ni-Sn catalyst for H-2 production from biomass-derived hydrocarbons. Science 2003, 300, 2075-2077. [CrossRef] [PubMed]

35. Echegoyen, Y.; Suelves, I.; Lazaro, M.J.; Moliner, R.; Palacios, J.M. Hydrogen production by thermocatalytic decomposition of methane over $\mathrm{Ni}-\mathrm{Al}$ and $\mathrm{Ni}-\mathrm{Cu}-\mathrm{Al}$ catalysts: Effect of calcination temperature. J. Power Sources 2007, 169, 150-157. [CrossRef]

36. Chen, T.; Zhou, M.; Wang, L.; Zhan, Z. The Synthesis and Characterization of Zinc-chromium Hydrotalcite-like Compound. Chin. J. Synth. Chem. 2002, 10,45-48.

37. Kim, S.-K.; Kim, K.-H.; Ihm, S.-K. The characteristics of wet air oxidation of phenol over CuOx/Al2O3 catalysts: Effect of copper loading. Chemosphere 2007, 68, 287-292. [CrossRef]

38. Villa, R.; Cristiani, C.; Groppi, G.; Lietti, L.; Forzatti, P.; Cornaro, U.; Rossini, S. Ni based mixed oxide materials for CH4 oxidation under redox cycle conditions. J. Mol. Catal. A-Chem. 2003, 204, 637-646. [CrossRef]

39. Schulze, K.; Makowski, W.; Chyzy, R.; Dziembaj, R.; Geismar, G. Nickel doped hydrotalcites as catalyst precursors for the partial oxidation of light paraffins. Appl. Clay Sci. 2001, 18, 59-69. [CrossRef]

40. Guoxiang, P.A.N.; Ni, Z.; Feng, C.A.O.; Li, X. Synthesis and reductive properties of new Ni-Sn-Al layered double hydroxides. J. Chin. Silic. Soc. 2009, 37, 1730-1734.

41. Bai, Y.; Lu, C.S.; Ma, L.; Chen, P.; Zheng, Y.F.; Li, X.N. Hydrogen production by aqueous-phase reforming of ethylene glycol over Pt catalysts supported on gamma-Al2O3 modified with ce and mg. Chin. J. Catal. 2006, $27,275-280$.

42. Shabaker, J.W.; Dumesic, J.A. Kinetics of aqueous-phase reforming of oxygenated hydrocarbons: $\mathrm{Pt} / \mathrm{Al}(2) \mathrm{O}(3)$ and Sn-modified Ni catalysts. Ind. Eng. Chem. Res. 2004, 43, 3105-3112. [CrossRef]

43. Shabaker, J.W.; Huber, G.W.; Dumesic, J.A. Aqueous-phase reforming of oxygenated hydrocarbons over Sn-modified Ni catalysts. J. Catal. 2004, 222, 180-191. [CrossRef]

44. Frusteri, F.; Freni, S.; Spadaro, L.; Chiodo, V.; Bonura, G.; Donato, S.; Cavallaro, S. H-2 production for MC fuel cell by steam reforming of ethanol over $\mathrm{MgO}$ supported $\mathrm{Pd}, \mathrm{Rh}, \mathrm{Ni}$ and Co catalysts. Catal. Commun. 2004, 5, 611-615. [CrossRef]

45. Yang, Y.; Ma, J.X.; Wu, F. Production of hydrogen by steam reforming of ethanol over a Ni/ZnO catalyst. Int. J. Hydrog. Energy 2006, 31, 877-882. [CrossRef]

46. Ni, M.; Leung, D.Y.C.; Leung, M.K.H. A review on reforming bio-ethanol for hydrogen production. Int. J. Hydrog. Energy 2007, 32, 3238-3247. [CrossRef]

47. Chen, G.; Xu, N.; Li, X.; Liu, Q.; Yang, H.; Li, W. Hydrogen production by aqueous-phase reforming of ethylene glycol over a Ni/Zn/Al derived hydrotalcite catalyst. RSC Adv. 2015, 5, 60128-60134. [CrossRef]

(C) 2020 by the authors. Licensee MDPI, Basel, Switzerland. This article is an open access article distributed under the terms and conditions of the Creative Commons Attribution (CC BY) license (http://creativecommons.org/licenses/by/4.0/). 